FACTA UNIVERSITATIS

Series: Visual Arts and Music Vol. 6, Nㅜㄹ 2, 2020, pp. 93 - 104

https://doi.org/10.22190/FUVAM2002093S

Original scientific paper

\title{
FEDERICO FELLINI'S FILM ORCHESTRA REHEARSAL FROM THE PERSPECTIVE OF NEW MUSICAL/INSTRUMENTAL THEATER*
}

\author{
UDC 785.1\%.161:792
}

\section{Djordje Stepanović}

Student of DAS, University of Arts, Faculty of Music, Belgrade, Serbia

\begin{abstract}
The genre of new musical/instrumental theater represents a new and complex endeavor in the field of art. Its complexity includes various artistic aspects such as acting, music, dance, performance, stage design, etc. The specificity of the plot of Fellini's film Orchestra Rehearsal (Prova d'Orchestra) provides a possibility to be interpreted from the perspective of the new musical theater. Different discourses that have permeated the film (e.g. verbal, musical, visual discourse, physical movements, and body language) represent the basic idea of the new genre. In the Orchestra Rehearsal, Federico Fellini managed to merge together different discourses of artistic expression in an extraordinary way, and thus bring his film closer to the genre of new musical theater.
\end{abstract}

Key words: new musical/instrumental theater, Orchestra Rehearsal, Federico Fellini, film.

\section{IL PRELUDIO}

The twentieth century represents an age in the history of mankind that abounds in a tremendous wave of knowledge and inventions in a wide range of human activities, such as science, art, technology, communications, etc. One of the outstanding innovations in the field of art is the appearance of the genre of new musical/instrumental theater ${ }^{1}$, whose roots, however, go back to the period of ancient Greek tragedy ${ }^{2}$. The emergence of this genre is in direct relation with opera, as a primary musical genre, in which elements of dramatic art are also used. "Yet a good deal of music theater rejects the grandeur of opera for many reasons including economics, the preference for non projected voices (extended voice, pop, non-

Received October 2020 / Accepted November 2020

Corresponding author: Djordje Stepanović

Student of DAS, University of Belgrade, Faculty of Music

E-mail: musictheory1994@gmail.com

*The paper was written under the mentorship of professor Ivan Brkljačić PhD, in the course of the Music theory, in the first year of $\mathrm{PhD}$ studies, academic 2018/2019.

${ }^{1}$ The terms new musical theater and instrumental theater are used as synonyms because they are closely related.

${ }^{2}$ Ancient Greek tragedy represents an important moment for the parallel development of the art of music and drama, and thus represents the basis for the future treatment of the genre of new musical theater. 
European styles or other kinds of singing), a desire for audience immediacy, or general aesthetic or philosophical preference for small-scale, unpretentious, small-theater work, closer in many ways to contemporary dance, dance theater, new theater and new performance art than to traditional opera". Subsequently, the new musical theater "absorbed the musical and artistic revolutions of the early twentieth century as well as the technological innovations of stagecraft and stage design, machinery and light, audio and video" (Salzman and Desi 2008, 4).

If we pay attention to the period just before the beginning of the twentieth century, we will see the significance of the year 1895, when the brothers Lumiére (Auguste and Louis Lumiére) organized the first public presentation of a film in Paris. For that reason, "film is one of the most recent facts and represents a very late date of human attainment, in the anthropological perspective from which it is viewed" (Mez 1975, 3). Today the medium of the film, which is also referred to as the "seventh art" (Ćirić 2016, 127), has fully entered the habits and everyday life of people, and it is no longer enough to just admire it as a phenomenon that came to light but should be understood in all its diversity. The subject of this paper is the film Orchestra Rehearsal (Prova d'Orchestra) of Federico Fellini (1920-1993), one of the most influential film directors and scenarist of the twentieth century, of Italian origin. The aim of this paper is to perceive the above mentioned film from the perspective of new musical/instrumental theater, although it cannot primarily be designated as belonging to this genre, because it does not happen at a given moment explicitly on stage or in a concert hall.

As a work of art Orchestra Rehearsal is an Italian satirical film made in 1979. The same year, this film was presented at the Cannes International Film Festival although it was not a direct competitor in the program. The music (soundtrack) for this film was composed by the famous Italian composer Nino Rota ${ }^{3}$ (Giovanni Nino Rota, 1911-1979), and it was also the last collaboration between Rota and Fellini because the composer died in early April $1979 .{ }^{4}$ In order for this film to be viewed from the perspective of a new musical/instrumental theater, it should be borne in mind that the new musical theater ,can be considered the confluence or adding up of language-like expressions: verbal or spoken language (the story; the libretto), physical movement or body language (gesture, dance), images or visual language (décor or design), and sound or musical language (pitch and rhythm; vocal and instrumental). The word 'language' is used here in the general sense of an organised communications system" (Salzman and Desi 2008, 13).

\subsection{La prima scena}

\section{LE SCENE}

Most of the time the film takes place in one location, and that is the oratory ${ }^{5}$ of the church, which dates back to the thirteenth century. Spatial static can be interpreted as if the

\footnotetext{
${ }^{3}$ Nino Rota has composed music for a number of Fellini's works, from his early films such as The White Sheik (Lo sceicco bianco), The Bullocks (I Vitelloni) and The Street (La Strada), to the Orchestra Rehearsal, after which he died (Bondanella 2002, 3).

${ }^{4}$ Apart from Nino Rota, contemporary composers of film music in 20th-century Italian cinematography were Ennio Morricone (1928-2020) and Francesco De Masi (1930-2005). They had written film music for some of the most famous Italian directors such as Sergio Leone, Brian De Palma, Lucio Fulci, Enzo G. Castellari, Giuseppe Tornatore, and others (Sadie 1980, 6772-6773).

${ }^{5}$ The used term oratory (oratorio) here does not mean a vocal-instrumental genre, but the literal meaning of the word oratorio, which in Church Latin means a space for a prayer (lat. orare - to pray).
} 
film is actually happening on stage (even if it does not), which is one of the features of the new musical theater, but also of theater in general. The first scene begins with quite inarticulate sounds of the voice of Zuanelli, an old score scrivener who checks the acoustics of the church. At the very beginning, the use of unconventional sounds, typical for the genre of new musical theater, is noticeable. Zuanelli's character has the role of an immediate narrator, who appears on the "stage" and connects certain events, from time to time. The oratory of the church contains the tombs of three Roman popes and seven bishops, which is known from the story of Zuanelli. Thus, this space acquires sacredness because it represents the link between the present moment and the past, and as a time parallel, it is the abovementioned relationship of the new musical theater with ancient Greek tragedy.

In order to convey the significance of the stage space as faithfully as possible, Zuanelli states that in 1781, the oratory became a real auditorium, a hall for vocal and instrumental concerts, because of its great acoustics. The sound in that hall is crystal clear and without echo, and all European courts envied the Italians on it. There is hardly any coincidence that this church was chosen to serve for the orchestra rehearsal. Famous ministers and ambassadors used to come to this hall to listen to the concerts. All these facts presented by Zuanelli contribute to the fact that the space of the "stage" takes on the characteristics of monumentality. However, the oratory is quite empty: on the left and right side there are benches for the believers, in front of them there is a pedestal for the conductor, and behind there is a ladder and a couple of carved, concrete panels. The central part of the oratory is empty, that is the place where the musicians will be later. The portraits of the composers (Mozart, Vivaldi...), which are placed on the walls of the church, allude to the concert place, moved from the conventional music hall, which indicates the modernist aspirations of the new musical theater. The interior, decoration and design of the stage are reduced and exude simplicity, so as not to distract the audience from the main events.

\subsection{La seconda scena}

After the first opening scene, a violinist appears in the hall and announces the arrival of television, which will make a documentary about the orchestra. The presence of television symbolically represents the presence of the audience through the lens of the camera, as an active participant in the action on the stage, which has an impact on the final design of the work of art. This is one of the important elements in the genre of new musical theater. Then, all the other musicians arrive slowly. While the pianist plays a composition at the piano, the other performers make noise while bringing and arranging chairs in the center of the hall, opposite the conductor's desk. In this scene "music does not accompany action, it rather is the action or at least an integral part of it. Soundproducing gesture and sound produced are to be seen as one integral music-theatrical action which has acoustic and visual components" (Heile 2006, 40). This is perceived as one of the principles of the new musical theater. It is also interesting to notice the sudden contrast, of a scene in which only one person is present, to an almost mass scene in which a "stage" is filled by a large number of musicians. The realization of such contrasts is not alien to the mentioned genre.

Just before the rehearsal begins, the musicians have informal conversations with each other that bring about a verbal discourse on the "stage". The trumpet player states the situation that happened to him while he was coming to the rehearsal. He could not cross the pedestrian crossing, although the green light was on because one driver was passing. He told the driver that he was rushing for the rehearsal of the orchestra, and the driver replied to him that it was 
not worth going, it was immediately obvious that he was useless. This situation reflects quite a marginalized position of artistic music nowadays, but also of art in general. In parallel with this scene, one of the clarinetists is listening to the broadcast of the football match on the radio, and a couple of other men gathered around him to hear the radio. The comic scene takes place while a trumpet player is playing, and as he blows air in the instrument, a balloon (which is actually a preservative) expands from the instrument, which bursts at the end, and the musicians around him start laughing. Frivolity of the musicians comes to light, and it will be highly expressed later in the film. During these events, the sounds of various instruments are played in the background for rehearsal indicating the existence of musical discourse (which permeates the mentioned stage events). These quite unconventional situations can be viewed as integral elements of the new musical theater, which implies to a certain extent a dose of the spontaneity of the musicians (performers) on the stage.

One of the representatives of the union whose duty is to inform all the musicians about the arrival of the television with cameras and reporters in order to record the rehearsal of the orchestra and interview the musicians comes in the next moment. In the new musical theater, the people on the stage are actors, musicians, and at the same time performers, the very characteristic of this film production of Fellini`s. The young violinist protests and announces that he will state in front of the camera how the representative of the union puts money of the musicians in his own pocket. One of the cellists joins this boycott and says: "You pay us poorly anyway, and now a television that pays nothing!" Here are the first sparks of dissatisfaction of the performers with their not so good position in society. The bad status of artistic music in the social milieu is also confirmed, due to the attitude of the state administration towards the profession and the way of financial, socio-cultural and media valorization of artistic musical creation and performance. During the discussion, the woman who plays the small organ, at the same time, listens to some explosions as if bombs are falling, and watches in astonishment. "External" factors of the kind will occur more and more frequently during the film. The presence of different sounds (explosions, organ sound), verbal expression (angry speech of the violinist and cellist), and body movements of the actors (sudden, almost threatening movements directed at the representative of the union) gather into one homogeneous image of the "theater" scene, like a new musical theater.

\subsection{La terza scena}

In the following scenes, a reporter with a camera comes to each musician with the intention that each of them should tell him something about his musical instrument. "Every musician from Fellini's orchestra, with the help of Rota's music, tells a story about his instrument. At the same time, it can be seen that the instruments tell their musical stories through the musicians who play them and who talk about them" (Brkljačić 2011, 7). First, the reporter comes to the pianist while she plays the piano casually. She stops playing and begins the story of her instrument spontaneously: "The piano is like a king who does not move from his throne. You should go to him, bow to him, and give him a chair. The piano is like a mythological animal. It is really an imperial instrument. All the pianos in the world are pianos. Playing only on your own piano is limiting, just like brakes to a car". At times, she occasionally plays during the story, while a few musicians gathered around the piano, listening to her carefully. Several permeated elements characteristic of the new musical theater can be noticed in this scene: through her story about the piano a verbal language is involved, movements of her hands while playing, gestures and facial expressions illustrate body 
language and physical movement, while the occasional presence of piano sounds represents the musical language.

The next is a young flutist, who graduated from the Academy of California, and who says that it is played softer there, and not so aggressive as here. With enthusiasm in her speech, she describes the flute as a delicate and discreet instrument, whose sound is most similar to the human voice, mysterious and incredibly natural. "The flute tames the beasts, what more do you want? Didn't Apollo awake dead creatures with his flute?", she says while holding her instrument firmly in the hands. Then, she turns the flute a few times, something like acrobatic movements, and passes it to the musician who is sitting next to her. She gets up and makes a turn body supported by her hands while several musicians around her laugh and applaud her. Such performative activities, that is, elements of acrobatics by the flutist, indicate the presence of the basic features of the new musical theater. The action of the scene is accompanied by music in the background. It is performed by a pianist, because "music has been an indispensable companion of 'moving images' since the birth of the film. The musical form is mostly dictated by the structure of the film" (Ćiric 2016, 128-129). There is also a combination of different languages (speech, sound, body movements) between the audience and the "stage", in the general sense of organized communication systems. They are associated with the new musical theater.

Other musicians (trombonists, percussionists, clarinetists, violinists, cellists) also tell a story about their own instrument and through the sound of the instrument, with more or less the same enthusiasm. In this way, an important element of the new musical theater was achieved, and that is the multidimensional role of the actors and the relationship narratoractor-musician/performer. The trumpet player's story is especially interesting. He perceives his trumpet as a passionate and wonderful instrument because the trumpet can express better and stronger what he feels inside, such as joy, sadness, silence. The trumpet for him is a portal to another dimension, the dimension of fulfillment, where everything is more intense and enchanting. From these statements, we can see the deep connection of the musician with his instrument, that is, how he expresses his mental states and emotions, through playing the instrument. The presence of alternating verbal and musical language with subtle physical movements on the "stage", embodies the primary idea of instrumental theater.

In a certain sense, this static unfolding of the plot, that is, the interviewing of musicians on stage is interrupted by a comic situation that gives dynamism to the entire plot of the film. One of the musicians sees a rat and then starts chasing him, thus creating chaos in the hall. The pianist climbs on a piano chair and screams, some musicians chant and shout, others just watch calmly, and two drummers, one with a broom and the other with a burning paper in his hand, chase the rats which are hiding behind a concrete panel leaning against the wall. The drummer grabs the rat by the tail and takes it outside, while the representative of the union calms down the situation in the hall. Once again, a scene atypical for the concert hall, but not so foreign to the new musical theater can be noticed. The permeation of verbal language, physical action on the "stage", and the sounds that accompany these events, indicate to the elements of the new musical theater.

\subsection{La quarta scena}

One of the important moments in the film is the arrival of the conductor of the orchestra. During the noise in the hall, the conductor is not present, but in the next moment, he is there, on the "stage", standing calmly behind the desk and watching the music score silently, 
while the situation is gradually calming down. The reporter comes to the conductor, but he is against recording for television. Nevertheless, he speaks calmly in Italian, but with an artificial German accent: "Rehearsal of the orchestra is like a workshop here - at least it should be like that - in which we will try to do something. We will try to build something. What and why, I haven't figured out yet..." These expressed thoughts of the conductor indicate that the work of art is created 'now and here' on the stage, which implies a certain dose of spontaneity. Not every movement and gesture of stage action can be predetermined, nor is it required from a performer in the instrumental theater genre. The primary role of the conductor is to lead a group of musicians in the "construction" of music, and metaphorically it represents one society and its supreme authority. In order to attract the musician's attention, he turns from the reporter to the orchestra, takes the conductor's baton and knocks on the desk. The rehearsal of the orchestra begins, and thus the "reign" of the conductor. The conductor is quite dissatisfied with the music and he orders the musicians to play with very specific nuances that border on absurd abstraction. He yells at the musicians, while several of them begin to undress under great effort and psychological pressure by the conductor. The performativity and complexity of the theatrical event is ubiquitous.

Tension is increased by the highly dynamic plot, which is realized by the permeation of musical, speech, and physical discourse, and generates an allusion to the instrumental theater. "Where are we? It looks like a football match? Did you replace me with a judge? You all need to be castrated!", the conductor says loudly, and the whole situation culminates with his throwing a music score at the musicians. At one moment, a small earthquake happens unexpectedly and all the musicians look up. Unconventional events on the „stage” permeate and enrich the dramatic flow of the film, which brings the Orchestra Rehearsal closer to the new musical theater. The conductor continues to shout hysterically: "Do you want to drive me crazy? Do you want my backside?! Here it is!" He turns his back and shows the musicians his backside, thus mocking them. Throughout this whole scene, the allegorical character of the narration, which is typical for this film, is noticeable. The conductor's authoritarian performance (his artificial German accent alluding to Hitler's dictatorship) begins to arouse anger, rage, and irritation among the musicians, and all of that represents metaphorically the Italian (but not only Italian) political scene, one individual person who "conducts" the entire nation. By permeating verbal elements (the conductor's speech), musical elements (playing a composition), and body movements and gestures (conducting, playing, undressing of musicians, throwing music score) on the "stage", the essential idea of the new musical theater is realized.

The representative of the union realizes that the situation is getting out of control, and therefore gives the orchestra a double pause. At that moment, the scene is moved from the oratory of the church to another place, which is not typical for the genre of new musical theater, but it is certainly a feature of the film medium. A television camera follows musicians who are drinking, smoking, and talking to each other in a nearby bar, while soft music from the radio is heard in the background all the time. The reporter passes from one musician to another in order to find out their opinions about the conductor of the orchestra, and he ranks their ideological thoughts, in a metaphorical sense. One musician notices that the conductor is a little hysterical, but within normal limits. However, the violinist intervenes vigorously with the statement that they no longer need such conductors and that a metronome would be quite sufficient. Moving her hands left and right, she imitates the pendulum of a metronome, while her voice imitates the sound of a tick-tick, a tick-tick, which is another of the theatrical moments in this film. There is a dialogue between the two musicians about their position in 
society. One of them states that almost all the members of the orchestra are of modest origin, and that also refers to their cultural level. The percussionist says: "All their lives, musicians are tied to a piece of wood or metal, where some of them blow, and others hit the string." The dissatisfaction of the musicians comes to surface, and the mutual intolerance of colleagues is noticed. The constitutive elements of the new musical theater are quite pronounced in this scene: musical discourse (constant presence of music, although in the background), body movements and gestures (imitation of the metronome by the violinist), and the verbal discourse (conversations between musicians).

\subsection{La quinta scena}

In the next scene, a representative of television is in the oratory of the church again to interview some of the musicians who did not go to the bar during the pause. He first comes to the tube player, who declares with a dose of sadness in his voice that he did not choose the tube, but the tube chose him, and he has always wanted to play that instrument. He begins his story: "The fact that no one liked the tube saddened me. Poor tube! That wind instrument was lonely like a stray dog! The tube looked like me a little bit sad, lonely, clumsy, and deaf as I am. I thought we should get together and I did. That was my destiny! I can't leave the tube anymore, we are real friends. In moments of melancholy, tube and I stand at the window, watch the moon and perform Verdi's solo". Then the tube player starts playing a melody from Verdi's composition, and at times he is joined by a harpist. By reviving an instrument (tube) on the stage, the feature of a new musical theater is noticed, that is, the combination of verbal and musical discourse, where the performer speaks about his instrument and through his instrument. This reveals a strong and unbreakable connection between the player and his instrument. He identifies with the tube, and expresses his deep feelings through its sound. A few important sentences about the understanding and experience of music are uttered by the present violinist in front of the reporter's camera: "In the sounds, everyone hears what they want to hear. The sound is subjective. The world is beautiful because it is different!" His words prompt to a conclusion as to how important music as art for a human being is, and how monotonous the world would be without music.

Then the camera comes to the oboist, who highlights his instrument as the most important in the orchestra. He states the fact that the oboe as an instrument is older than all the others. It originates from China, and it is the most complicated, delicate and lonely instrument. Such are the oboists, isolated, and lonely. The identification of a musician with the characteristics of his instrument indicates that he is expressed through the instrument. But the importance of the oboe in the orchestra is emphasized because it is authoritative, and it regulates the range between the highest and lowest intonation among all instruments. Because of this privilege, the violin hates the oboe and vice versa. This fact indicates the instrumental theater because there is some amount of intolerance between the instruments themselves as if they were human beings, by which actorsmusicians are represented. It is also noticeable that the musicians are aware that there is discord in the orchestra rather than the good and pleasant atmosphere which is reflected in their unified creation of music. Metaphorically it symbolizes discord among the people. The oboe player illustrates the previously expressed thoughts by performing a certain melody and thus reviving his instrument: ,The oboe is an instrument of spiritual uplifting, an inside view that allows you to feel the color of the sound. I play and see the gilded, illuminated 
space around me, the colors of the sun. A strong shimmer... Look, my hands are shaking." In this scene, the elements of verbal and musical language are primarily expressed, while physical movements are more reduced, but this again indicates the presence of theatrical elements, which can also be directed to the genre of new musical theater.

\subsection{La sesta scena}

Another scene, apart from the one in the nearby bar, where the action does not take place on the "main stage" in the oratory of the church, is an interview with the conductor and it is carried out in a small, separate room, which is located within the church. The conductor expresses his frustrations concerning the impossible contradictions of his leading role. He begins his speech with a series of rhetorical questions: "What do you want to know? That music is an integral part of life? I would like to ask you something, is there music? No? Then there is no life either! What is the meaning of music today? Do you think that people who come to concerts know what music is? They believe that they are more intelligent because they feel emotions in their stomach, and that is important".

The conductor emphasizes his pessimistic opinion towards the whole situation with tragicomic elements, denying the existence of music and thus life. In the next moment, he changes his opinion: "I should always be optimistic and intelligent. Music is life. As I conduct, I feel like the master of life. It's like I'm a king! No! Want to really know how I feel? As a hired guard who constantly needs to shoot someone in the backside... Genius is always on the verge of whimsy and bizarreness". In these opinions of the conductor, one can see his authoritarian instinct and urge to lead an inconsistent mass of people. This refers to the authority represented by an individual person or a small group of people, who want to govern the entire nation, in a figurative sense.

The conductor continues his speech as he remembers his first appearance on stage: "I was most impressed by the deep silence in front of me. I gave the musicians a signal to start and got excited to see that my conductor's baton made the orchestra sound united. The sound of the orchestra was created by my hands. The hands took the orchestra out of the silence and then brought them back to silence... And today we are all the same. I should look like the first violinist, who has fingers similar to a butcher's". The opinion of the conductor is that his role should not be equal to the role of other musicians in the orchestra, because he is still the leader of that particular social group. With a dose of disappointment in his voice, he concludes his speech from the position of conductor and musician today in the orchestra: "Did you say director of the orchestra? That word no longer has any meaning. The director of the orchestra is like a priest who must have a church and believers. Otherwise, the church collapses, and the believers become atheists. Music is always sacred, and every concert is like a mass". The words of the conductor, one can notice that the choice of the church as the place of the film (and "stage") is not accidental and that the music is presented symbolically as a universal religion, which should unite all people. At that point the earthquake, just like a few moments before, happens again, but the conductor continues his speech, not paying any attention to it: "There is only mistrust between me and my musicians. One musician fights against the other, and there is suspicion that destroys trust. There is only contempt, hatred, and anger for what has been lost and will never return, and there is a lack of respect among musicians. That's how we play. We are driven only by a common hatred. Like a ruined family..." As the leader of a certain group of people, the conductor is dissatisfied with his position, the disrespect that musicians show 
towards him, the intolerance that reigns among the musicians, and therefore it is not possible to create music if there is no harmonious, orderly relationship and tolerance between performers in the orchestra and performers in any other group of people. Then he sits down at the piano and plays some chords. As he plays the final dissonant chord, the electricity in the whole church disappears. It is no coincidence that the final chord is dissonant because it hints to the events in the last scene of the film.

Verbal discourse is dominant in this scene, because the conductor expresses his thoughts all the time, while visual and musical discourse and physical movements are reduced to almost the lowest level. Only at the beginning (while the actor is changing his shirt) and at the end of the scene (when the actor gets up and goes to the piano), the conductor moves around the room, while during the rest of the scene he is mostly static, as he sits on the couch and talks. The music only joins in at the end of the scene, when the conductor sits down at the piano to play a few chords. The interior of the room is so simplified that it contains only a few items: a couch, a chair, a table with a bottle of champagne on it, and a piano. There are no details that would distract the eyes and attention of the audience from the personality of the conductor and his speech. This scene is the farthest from the point of view of the new musical theater and it is much more reminiscent of a monodrama in the theatre, in which there is just as much music as a single actor creates through the mere expression of text (through diction and intonation).

\subsection{La scena finale}

Under the light of a candle brought by old Zuanelli, the conductor leaves his room and comes to a darkened oratory where he finds a completely chaotic scene. Musicians write revolutionary phrases on the walls of the old church and throw garbage at the portraits of composers. The percussionists play the drums, while the others, like enraged animals, shout a phrase against their oppressive and tyrannical conductor: "Director, director, we don't want you anymore! You can go, it's better for you"! The indignation of the actors-musicians is slowly but surely increasing, and the oratory of the church is becoming a theatrical stage of chaos. An angry cellist crumples the score throwing them away and shouts: "Music should be a public art and serve to everyone! No class differences"! Earthquakes happen again, and portraits of the composers fall down from the walls, while something dark begins to drip from above. One of the musicians says out loud: "We don't give the power to conducting baton! Get out, directors! We want our music now"! A group of musicians brings a large wooden metronome, which replaces the role of conductor, in the following moments. "Let's give the conductor's throne to the metronome, metronome, and emperor! We decide about music, rhythm, and cadence! We don't want anyone to conduct with us!" Almost all of the musicians of the orchestra chant, expressing hatred towards its conductor. A violinist, in a fit of rage, throws a chair on the big metronome, and then the whole situation gets out of control. The musicians start fighting and slapping each other, pouring water on themselves, and even throwing instruments, and all of which culminates with random shots from a violinist's gun. A significant number of unexpected and eccentric events, which increase the tension of the narrative flow, can be interpreted through the genre of instrumental theater. The conductor sits and calmly watches the chaos that is happening in front of him.

The highlight of this last scene, and of the entire film, is the moment when an incredibly large ball (whose presence is almost inexplicable) crashes the wall of the church with divine wrath. The wall falls down and kills the harpist, who was sitting next to her instrument, near the wall. This situation indicates that hatred and discord among people can lead to fatal and 
tragic consequences. While the stunned musicians silently watch this tragedy in a cloud of dust of rubble, the conductor appears in front of them with a motivational speech: "Music can save us. Follow the score, follow the way my hands show you. We are musicians and we are here to try. Don't be afraid, the rehearsal continues. Take your seats, musicians!" Motivated musicians take their instruments to perform the music of redemption, in the middle of the ruins. In this moment, the strength and power of music as a universal faith which can unite people, regardless of all obstacles, is realized. In the end, the conductor's words of praise fade and once again lead to his perfectionist dissatisfaction. Expressing his disturbing criticism, the conductor speaks loudly to the orchestra with a fake German accent: "It may be useful to remind ourselves that noise is not music. Where are you? Is this a football match? Do you think I'm a judge? Where did you lose your breath, brass players? May it be in the stupid chatter? Everyone, play with all your capacity and with enthusiasm! Let the trumpets make the dead come alive! Are you musicians or not? I want a sound of the color of fire! Musicians, da capo, play from the beginning!" The conductor ends his speech with the last words in Hitler's accent and the musicians play united again. This behavior of the musicians "led to complete anarchy, which culminated in the anger caused by the conductor's dictatorship, which in the end, after the cataclysmic disintegration of everything in the orchestra, is restored by the same conductor's dictatorship" (Brkljačić 2011, 7).

The last scene, and the end of the film at the same time, is filled with tension, action on the "stage" and dynamic events, from the complete destruction of the oratory of the church by the musicians, their shouting, chanting, and mutual physical attacks, to the completely calm atmosphere of united, harmonious playing the music. All theatrical rules that imply the permeation of several different discourses on the stage have been realized. Verbal language (communication between conductor and musicians), musical language (playing the instruments together), physical movement, and body language (all body movements and gestures of musicians on the "stage" during the last scene) as well as visual language, contributed to the impressive ending of this film.

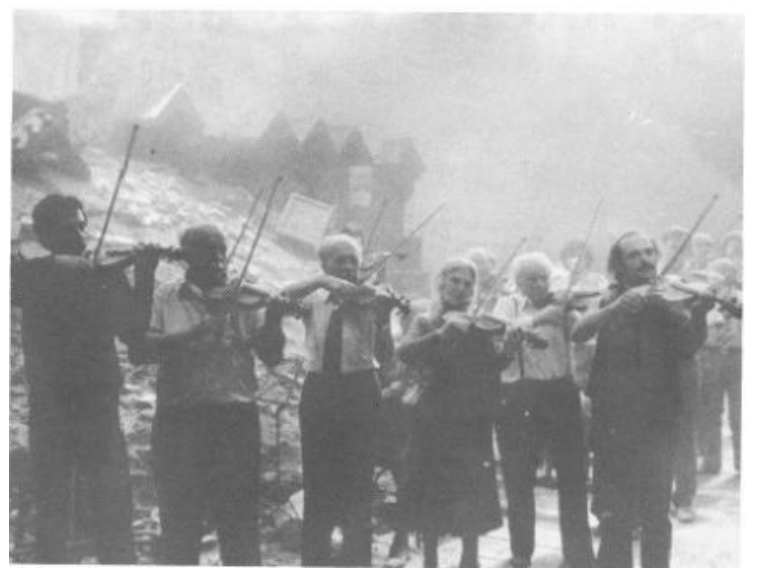

Fig. 1 Federico Fellini, Orchestra Rehearsal, the last scene: musicians playing in ruins ${ }^{6}$

\footnotetext{
${ }^{6}$ The image is taken from: J. E. Lahosa, Concertino para el apocalipsis -"Prova d'Orchestra“ by Federico Fellini, El Ciervo 96, No. 347, 1980, 40.
} 


\section{Il POSTLUDiO}

It can be concluded that the Fellini's film Orchestra Rehearsal significantly meets the criteria related to the genre of new musical/instrumental theater. The spatial static of the movie, which takes place almost entirely in the oratory of the church (except for the scene in the bar and the conductor's room), marks a theatrical element as if everything is happening on one stage. The interaction of different languages of communication, such as verbal, musical, visual language, physical movements, and body language, contribute to the theatrical realization of the film scenes.

Music, as one of the most important elements of the new musical theater, is an integral element in most scenes in the film. "In the domain of audio-visual art, especially in the film, music is combined with sound effects and human speech into a single expressive flow. It can be analyzed as a multi-layered sound component or a counterpoint flow of music dialogue and sound effects" (Vartkes 2007, 17). Fellini, "an artist who preferred the art of reality and a man who believed that dreams were the most sincere expression for a human being"7, has masterfully managed to unite different discourses of human expression and turn them into a seemingly ordinary situation in the life of an orchestra musicians. However, it is an allegorical story and critique directed to Italian society (but not only Italian) and its political scene at that time (but obviously not only at that time).

"I don't think my films are misunderstood when they are accepted for different reasons. This diversity of reaction doesn't mean that the objective reality of the film has been misunderstood. Anyway, there is no objective reality in my films, any more than there is in life" (Burke and Waller 2002, 3). It was with this that the genre of instrumental theater gained real-life, force, and its logical form, regardless of the fact that it is presented through the art of film.

\section{REFERENCES}

Bondanella, P., (2002), The Films of Federico Fellini, Cambridge University Press, New York.

Brkljačić, I., (2011), "Istar - instrumentalni teatar. Teorijska studija o istoimenom ciklusu nascentnih muzičkih karikatura za scensko izvođenje u pozorišnom dekoru" ["Istar - instrumental theater. Theoretical study of the eponymous cycle of nascent musical caricatures for stage performance in theatrical decor"], Muzički talas 40, Vol. 17: pp. 2-33.

Burke, F. and M. R. Waller, (2002), Federico Fellini: Contemporary Perspectives, University of Toronto Press, Toronto.

Heile, B., (2006), The Music of Mauricio Kagel, Ashgate Publishig Limited, Farnham.

Lahosa, J. E., (1980), "Concertino para el apocalipsis - „Prova d'Orchestra“ de Federico Fellini", El Ciervo 96, No. 347: pp. 40.

Mez, K., (1975), Jezik i kinematografski medijum [Language and cinematic medium], Institut za film, Beograd.

Sadie, S., (1980), The New Grove Dictionary of Music and Musicians, Volume 12, Macmillan Publishers Limited, London.

Salzman, E. and T. Desi, (2008), The New Music Theater. Seeing the Voice, Hearing the Body, Oxford University Press, New York.

\footnotetext{
${ }^{7}$ Bondanella 2002, 4.

${ }^{8}$ A quote by Federico Fellini; Frank, Burke and Marguerite R. Waller, Federico Fellini: Contemporary Perspectives, Toronto: University of Toronto Press 2002, 3.
} 
Vartkes, B., (2007), Muzika kao primenjena umetnost [Music as an applied art], Radio-televizija Srbije, Centar za istraživanje javnog mnjenja, programa i auditorijuma, Beograd.

Ćirić, M., (2016), "Mediji i tradicionalne forme umetnosti: film kao prostor plasiranja umetničke muzike" ["The media and traditional art forms: film as a space for artistic music placement"], u: Vlado S. Milošević (ur.), Tradicija kao inspiracija, Akademija umjetnosti Univerziteta u Banjoj Luci, Banja Luka: pp. 127-139.

\section{PROBA ORKESTRA FEDERIKA FELINIJA IZ VIZURE NOVOG MUZIČKOG/INSTRUMENTALNOG TEATRA}

Žanr novog muzičkog/instrumentalnog teatra predstavlja novi i kompleksan poduhvat na polju umetnosti. Njegova složenost obuhvata različite umetničke aspekte kao što su gluma, muzika, ples, performans, dizajn pozorišne scene i tako dalje. Specifičnost radnje Felinijevog filma „Proba orkestra" (Prova d'Orchestra) pruža mogućnost da bude tumačen iz vizure novog muzičkog teatra. Prožimanje različitih diskursa (na primer: verbalni, muzički, vizuelni diskurs, fizički pokreti i govor tela) u filmu predstavlja osnovnu ideju pomenutog novog žanra. Federiko Felini je u „Probi orkestra" na izvanredan način uspeo da poveže različite diskurse umetničkog izražavanja, i tako svoje filmsko ostvarenje približi žanru novog muzičkog teatra.

Ključne reči: novi muzički/instrumentalni teatar, „Proba orkestra”, Federiko Felini, film. 